\title{
Analisa Pemilihan Konsep Desain Alat Pirolisis Asap Cair untuk Pengawetan Ikan Bandeng
}

\author{
Dhimas Satria*, Haryadi, Rina Lusiani, Erni Listijorini, Nidya Jullanar Salman, Andi Abdillah \\ Jurusan Teknik Mesin, Universitas Sultan Ageng Tirtayasa \\ Jl. Jenderal Sudirman km. 3, Cilegon, Banten \\ *E-mail: dhimas@untirta.ac.id
}

Diterima: 14-07-2021; Direvisi: 26-07-2021; Dipublikasi: 27-08-2021

\begin{abstract}
Abstrak
Ikan bandeng adalah salah satu produk hasil perikanan yang menjadi produk unggulan di Provinsi Banten. Kualitas kesegaran ikan bandeng menjadi sesuatu yang harus dipenuhi oleh produsen ikan bandeng. Permasalahan terkait kesegaran ikan bandeng ini yang sering terjadi mengingat penjualan yang tidak selalu habis, sementara ikan bandeng dapat bertahan hanya dalam 24 jam tanpa ada proses pengawetan sebelumnya. Disamping itu, pada ikan bandeng memiliki susunan jaringan yang longgar, kandungan nutrisi dan juga kandungan air yang cukup tinggi sehingga menjadi media pertumbuhan mikroba yang dapat menyebabkan ikan bandeng menjadi lebih mudah mengalami penurunan kualitas atau pembusukan (perishable food). Sehingga pada penelitian ini dilakukan analisa pemilihan konsep desain alat pirolisis yang berfungsi untuk memproduksi asap cair melalui proses pembakaran suhu tinggi dengan sedikit $\mathrm{O}_{2}$, dengan konstruksi yang sederhana sehingga tidak membutuhkan keahlian khusus bagi pengguna pemula. Metodologi yang dipergunakan dalam menganalisa pemilihan konsep desain alat pirolisis asap cair untuk pengawetan ikan bandeng adalah menggunakan metode Pahl and Beitz dan juga metode Quality Function Deployment. Hasil penelitian adalah mendapatkan varian terbaik yaitu Varian 4 yaitu gas LPG - udara - terbuka counter flow. Adapun keseluruhan pemilihan konsep desain alat pirolisis asap cair untuk pengawetan ikan bandeng yaitu: proses pembakaran mengunakan gas LPG, proses pendinginan menggunakan air, mekanisme pembakaran adalah tertutup (menggunakan drum), arah aliran kondensor adalah counter flow (berlawanan arah), dan konsep bentuk alat adalah silinder.
\end{abstract}

Kata kunci: konsep desain; alat pirolisis; asap cair; ikan bandeng

\begin{abstract}
The badger is one of the products of fisheries that are a predominant product in the banten province. The quality of freshness of the bandeng fish becomes something that must be met by the bandeng producers. The frequent question of fresh bandings is this because of the infrequent sales, while the goat can last only 24 hours with no preservative process. Moreover, the bandwidth has a loose array of tissues, nutrients as well as water content high enough to become a microbial growth medium that can make the catfish more susceptible to drop in quality or decay. So that in this study an analysis of the selection of the design concept of a pyrolysis device that functions to produce liquid smoke through a high temperature combustion process with a small amount of $\mathrm{O}_{2}$ was carried out, with modest construction that requires no special skill for young users. The methodology employed in analyzing selection of a draft design of liquid smoke pirolytic devices for the preservation of the catfish is employed by the method pahl and beitz and also the quality function deployment. Research is getting the best variant, a variant 4, which is the ipg gas open-air - counter flow. As for the overall selection of liqued-smoke pyrotechnic devices for the preservation of the Billy goat: burning processes used gas LPG, cooling with water, burning mechanisms are closed (using drums), the direction of condenser is a flower-flow counter, and the toolform concept is a cylinder.
\end{abstract}

Keywords: design concepts; pyrolysis tools; liquid smoke; catfish

\section{Pendahuluan}

Pengawetan makanan merupakan suatu teknologi yang digunakan banyak produsen makanan untuk mendapatkan produk makanan yang tahan lama, tetapi aman bagi tubuh manusia. Saat ini berkembang cara pengawetan makanan dengan menambahkan zat aditif yang bersifat alami. Secara lebih khusus, pengawetan Beberapa metode pengawetan makanan, khususnya pada ikan yaitu pengawetan dengan suhu tinggi, pengawetan dengan suhu rendah, pengasapan, penggaraman dan metode asap cair [1]. Dan metode asap cair adalah salahsatu yang banyak dimanfaatkan untuk pengawetan bahan makanan. 
Asap cair merupakan produk dari pirolisis tanaman atau kayu yang dilakukan pada suhu $400^{\circ} \mathrm{C}$ [2]. Pemanfaatan asap cair adalah dapat mengawetkan bahan makanan ikan dan daging, disamping juga dapat dimanfaatkan untuk pemberi citarasa, aroma dan juga tekstur. Hal ini karena pada asap cair terdapat senyawa asam, karbonil dan fenolat [3]

Metode asap cair untuk pengawetan bahan makanan, termasuk ikan dan daging, lebih praktis dan lebih aman dibandingkan dengan menggunakan metode pengasapan yang dilakukan secara tradisional. Hal ini disebabkan pada metode pengasapan secara tradisional mengandung senyawa Policyclyc Aromatic Hydrokarbon (PAH) atau biasa disebut senyawa karsinogenik yang merupakan salah satu senyawa yang dapat menyebabkan terjadinya penyakit kanker [4]. Tanaman kelapa dijumpai di banyak daerah di Indonesia \& tempurung kelapa merupakan bahan baku yang baik untuk mendapatkan asap cair, sehingga tanaman kelapa adalah tanaman yang mempunyai potensi tinggi sebagai bahan baku asap cair [5]. Kandungan pada tanaman kelapa, lebih khususnya tempurung kelapa, adalah lignin sebesar 29,4\%, air $8 \%$, selulosa 26,6\%, pentosa 27,7\%, uronat anhidrat 3,5\%, pelarut ekstraksi 4,2\%, abu 0,6\% [6]. Arang aktif tempurung kelapa akan menciptakan asap dalam proses pembuatannya, kemudian asap ini dengan melalui tahap kondensasi, akan berubah menjadi asap cair dengan cara mengubahnya dari fase gas menjadi fase cair. Asap cair tempurung kelapa mempunyai fenol memiliki fungsi sebagai anti oksidan yaitu aksi mencegah proses oksidasi senyawa protein dan lemak sehingga dengan demikian tidak dapat terjadi proses pemecahan senyawa serta akan memperpanjang masa simpan bahan makanan [7].

Selain itu, asap cair juga bisa didapatkan dari pengembunan asap yang merupakan hasil penguraian senyawa organik yang terdapat dalam tempurung kelapa yang terjadi pada saat proses pirolisis. Sewaktu proses pirolisis akan terbentuk berbagai macam senyawa. Senyawa yang ada pada asap dikelompokkan ke dalam beberapa golongan yaitu fenol, karbonil (terutama keton dan aldehid), asam furan, alkohol dan ester, lakton, hidrokarbon alifatik, dan hidrokarbon polisiklis aromatis [8].

Salah satu pemanfaatan asap cair adalah untuk pengawetan pada ikan bandeng. Ikan bandeng mempunyai banyak kelebihan dan ciri khas, antara lain mempunyai duri yang halus dan berstruktur padat, danging ikan berwarna putih bersih dan mempunyai tulang yang keras. Disamping ikan bandeng juga mempunyai rasa yang gurih, khas dan mempunyai asam amino yang dibutuhkan oleh tubuh.

Ikan bandeng adalah salah satu produk hasil perikanan yang banyak dihasilkan dan juga salah satu produk unggulan di Provinsi Banten. Kualitas ikan bandeng, dalam hal ini kesegaran, menjadi sesuatu yang harus dipenuhi oleh produsen ikan bandeng, baik petani maupun penjual ikan bandeng. Permasalahan terkait kesegaran ikan bandeng ini yang sering terjadi mengingat penjualan yang tidak selalu habis, sementara ikan bandeng dapat bertahan hanya dalam 24 jam tanpa ada proses pengawetan sebelumnya. Disamping itu, pada ikan bandeng memiliki susunan jaringan yang longgar, kandungan nutrisi dan juga kandungan air yang cukup tinggi sehingga menjadi media pertumbuhan mikroba yang dapat menyebabkan ikan bandeng menjadi lebih mudah mengalami penurunan kualitas atau pembusukan (perishable food). Sehingga diperlukan suatu penanganan khusus untuk mengatasi permasalahan perishable food tersebut [9]. Salah satu bentuk solusi dari permasalahan ikan bandeng yang tidak langsung habis dalam 24 jam dan juga kemungkinan mengalami perishable food pada ikan bandeng, maka perlu diperhatikan terkait metode pengawetan ikan bandeng terbaik.

Pembuatan asap cair dari tempurung kelapa, tongkol jagung, dan bambu menggunakan proses slow pyrolysis telah dilakukan oleh Karolus Boromeus Reta (2013), dimana hasil dari proses pirolisis ini berbentuk bio-arang, tar serta asap cair grade 3 [10]. Kemudian Eka Pratiwi Mentari (2017) juga telah melakukan pembuatan dan juga pengujian asap cair dari tempurung kelapa dan tongkol jagung yang akan digunakan sebagai bahan pengawet ikan dengan menggunakan metode perbandingan campuran banyaknya tongkong jagung dan tempurung kelapa menjadi parameter yang diukur 
dalam penelitian ini, parameter yang diuji yaitu kualitasikan yang dihasilkan dari asap cair dilihat dari aroma, tekstur, warna, bau dan rasa pada ikan [11]. Sementara untuk alat uji kinerja alat pembuat asap cair telah dilakukan oleh Syafri Syafri dan Sri Aulia Novita (2013) dengan metode rancangan dilakukan dengan pendekatan rancangan fungsional dan rancangan struktural. Pada waktu pengujian dilakukan dua variabel dalam menghasilkan asap cair yaitu pada kondisi air pendingin bergerak dan pada kondisi air pendingin yang diam [12].

Pada penelitian sebelumnya sudah didapatkan hasil bahwa salah satu metode pengawetan ikan bandeng terbaik adalah dengan menggunakan metode asap cair. Sehingga pada penelitian ini dikembangkan dari sisi konsep desain berbasis diagram fungsi, yaitu proses pembakaran, proses pendinginan, mekanisme pembakaran, arah aliran kondensor, dan konsep bentuk alat, yang belum dilakukan oleh penelitian-peneltian sebelumnya yang terkait.

Tujuan dari penelitian adalah mendapatlkan konsep desain terbaik alat pirolisis yang terbaik yang menghasilkan asap cair melalui proses pembakaran suhu tinggi dengan sedikit $\mathrm{O}_{2}$ untuk pengawetan ikan bandeng berbasis diagram fungsi.

\section{Metodologi}

Metodologi yang dipergunakan dalam menganalisa pemilihan konsep desain alat pirolisis asap cair untuk pengawetan ikan bandeng adalah menggunakan metode Pahl and Beitz [13][14] [15] dan juga metode penerapan fungsi kualitas (quality function deployment) [16] [17]. Metodologi tersebut antara lain meliputi langkah-langkah sebagai berikut: menentukan diagram fungsi, menentukan requirement list, analisa house of quality, penentuan spesifikasi, penentuan varian terbaik, dan konsep alat.

Adapun langkah-langkah untuk pemilihan konsep desain alat pirolisis asap cair dapat dijabarkan beberapa langkah:

1. Mengidentifikasi teori yang berkaitan dengan alat pirolisis penghasil asap cair beserta fungsi dan mekanismenya,

2. Menganalisa disain alat pirolisis penghasil asap cair yang ada sebelumnya agar dapat dipelajari dan dikembangkan pada varian-varian bentuk lain.

Material yang dipilih untuk digunakan sebagai material rangka alat pirolisis ini adalah material yang mendapatkan perlaakuan [18], yaitu material besi galvanis dikarenakan dalam operasi alat pirolisis ini bersentuhan dengan suhu dan tekanan yang tinggi, oleh karena itu diperlukan material rangka yang tahan terhadap korosi dan suhu tinggi.

\section{Hasil dan pembahasan}

\subsection{Diagram Fungsi}

Dalam Perancangan alat pirolisis asap cair untuk pengawetan ikan bandeng, terdapat beberapa fungsi tingkatan sebagai berikut :

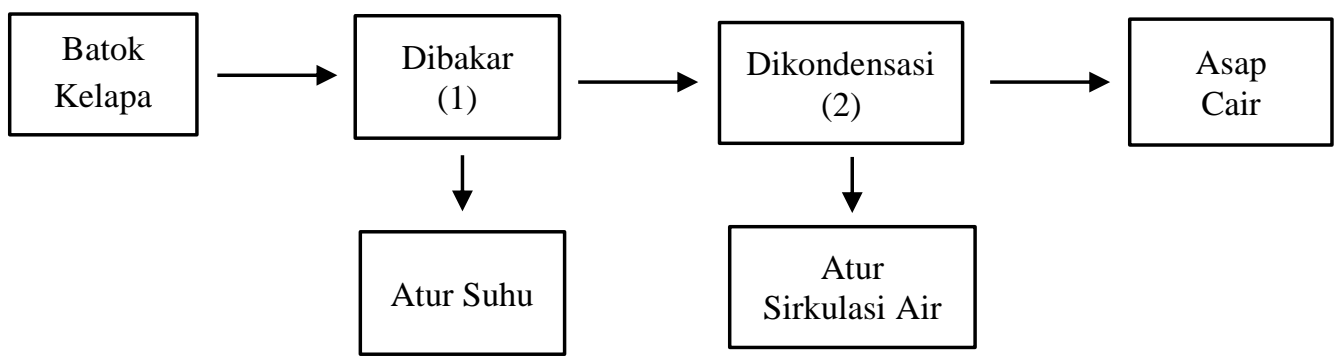

Gambar 1. Diagram fungsi alat pirolisis asap cair untuk pengawetan ikan bandeng 
Dalam proses perancangan perlu menentukan fungsi dari alat agar sesuatu yang di rancang dapat bekerja sesuai dengan kebutuhan konsumen. Pada gambar 1, yaitu diagram fungsi, dijelaskan uraian dari proses perancangan alat, yaitu dimulai dengan input berupa batok kelapa dan menghasilkan output dari alat pirolisis ini adalah asap cair. Penjelasan singkat sesuai dengan diagram fungsi yaitu, batok kelapa dimasukkan kedalam reaktor untuk dilakukan proses pembakaran yang memerlukan pengaturan suhu, langkah selanjutnya asap hasil pembakaran dikondensasikan menggunakan air pendingin yang selanjutnya akan menghasilkan asap cair yang ditampung dalam wadah.

\subsection{Requirement List}

Tabel 1. Requirement list perancangan alat pirolisis asap cair untuk pengawetan ikan bandeng

\begin{tabular}{|c|c|c|}
\hline \multirow[t]{2}{*}{ Requirement } & \multirow[t]{2}{*}{ Penjelasan } & \multirow[t]{2}{*}{$\begin{array}{c}\text { Demands }=\mathrm{D} \\
\text { Wishes }=\mathrm{W}\end{array}$} \\
\hline & & \\
\hline Fungsional & $\begin{array}{l}\text { Mampu menghasilkan asap cair sebagai pengawet } \\
\text { ikan bandeng. }\end{array}$ & $\mathrm{D}$ \\
\hline Rangka & Desain rangka mampu menopang beban. & $\mathrm{D}$ \\
\hline \multirow{4}{*}{ Operasi } & $\begin{array}{l}\text { Pengoperasian mudah, hanya dibutuhkan satu } \\
\text { orang operator. }\end{array}$ & $\mathrm{W}$ \\
\hline & Tingkat polusi yang dihasilkan rendah. & $\mathrm{D}$ \\
\hline & Alat dapat dipindahkan & $\mathrm{W}$ \\
\hline & Biaya operasi rendah & $\mathrm{W}$ \\
\hline \multirow{2}{*}{ Pembuatan } & Material substitusi tersedia banyak di pasaran. & $\mathrm{W}$ \\
\hline & Biaya pembuatan murah & $\mathrm{W}$ \\
\hline Keamanan & $\begin{array}{l}\text { Aman bagi operator dan lingkungan sekitar saat } \\
\text { alat beroperasi. }\end{array}$ & $\mathrm{D}$ \\
\hline Perawatan & Perawatan mudah & $\mathrm{W}$ \\
\hline
\end{tabular}

Pada penyusunan requirement list akan di jabarkan kebutuhan dari konsumen untuk alat pirolisis. Berdasarkan hasil survey yang dilakukan pada salah satu petambak dan pedagang yang terdapat di Domas, Kabupaten Serang, Banten. Dari hasil survey tersebut dapat disimpulkan beberapa kebutuhan alat yang harus dipenuhi yang selanjutnya akan diteruskan menjadi requirement list sehingga dapat ditentukan house of quality dari alat pirolisis penghasil asap cair. Berikut requirement list dari alat pirolisis:

1. Mampu menghasilkan asap cair sebagai pengawet ikan bandeng.

2. Desain rangka mampu menopang beban.

3. Pengoperasian mudah hanya dibutuhkan satu orang operator. 
4. Tingkat polusi yang dihasilkan rendah.

5. Alat dapat dipindahkan.

6. Biaya operasi alat rendah.

7. Material substitusi alat mudah di temukan di pasaran.

8. Biaya pembuatan alat murah.

9. Aman bagi operator dan lingkungan sekitar saat alat beroperasi.

10. Biaya perawatan murah.

Penentuan requirement list disajikan kembali dengan penjelasan pada tabel 1 dibawah ini, yaitu $\mathrm{D}=$ Permintaan dan $\mathrm{W}=$ Harapan

\subsection{Analisa House of Quality}

Rumah kualitas atau biasa disebut juga House of Quality (HoQ) merupakan tahap pertama dalam penerapan metodologi Quality Function Development (QFD). Berdasarkan requirement list pada tabel 1, maka dibuatlah skala prioritas dan House of Quality untuk perancangan alat pirolisis penghasil asap cair ini seperti terlihat pada tabel 2. Sedangkan House of Quality disajikan pada gambar 2.

Tabel 2. Skala prioritas perancangan alat pirolisis asap cair untuk pengawetan ikan bandeng

\begin{tabular}{|c|c|c|c|c|c|c|c|c|c|c|c|c|c|c|c|c|c|c|}
\hline Requirement List & & & & & & & Iat & iks & Kor & lasi & & & & & & Sum & $\%$ & Rank \\
\hline Pengoperasian mudah & 1 & 1 & 1 & 0 & 0 & & & & & & & & & & & 3 & 20 & 2 \\
\hline Tingkat polusi rendah & 0 & & & & & 1 & 0 & 0 & 0 & & & & & & & 1 & 6,7 & 3 \\
\hline Alat dapat dipindahkan & & 0 & & & & 0 & & & & 0 & 1 & 0 & & & & 1 & 6,7 & 3 \\
\hline Biaya operasi rendah & & & 0 & & & & 1 & & & 1 & & & 1 & 1 & & 4 & 26,6 & 1 \\
\hline Perawatan mudah & & & & 1 & & & & 1 & & & 0 & & 0 & & 1 & 3 & 20 & 2 \\
\hline Biaya pembuatan rendah & & & & & 1 & & & & 1 & & & 1 & & 0 & 0 & 3 & 20 & 2 \\
\hline
\end{tabular}

Keterangan: 1 = Prioritas, $0=$ Bukan Prioritas

\subsection{Penentuan Spesifikasi}

Tahap ini merupakan tahap pengumpulan informasi dari kebutuhan pengguna alat pirolisis penghasil asap cair yaitu pedagang ikan bandeng. Lalu membuat kesimpulan tentang spesifikasi apa saja yang dibutuhkan dan diinginkan untuk alat pirolisis penghasil asap cair ini dengan metode House of Quality. Alat yang akan direncanakan berdasarkan permintaan costumer adalah sebagai berikut:

$$
\begin{array}{ll}
\mathrm{m}: \text { Kapasitas reaktor } & =\leq 10 \mathrm{~kg} \\
\text { Safety factor } & =\geq 2 \\
\text { Sumber energi (reaktor) } & =\text { Gas LPG }
\end{array}
$$


Dhimas Satria dkk /Jurnal Rekayasa Mesin

p-ISSN: 1411-6863, e-ISSN: 2540-7678

Vol.16, No.2, Agustus 2021, hal. 189-199
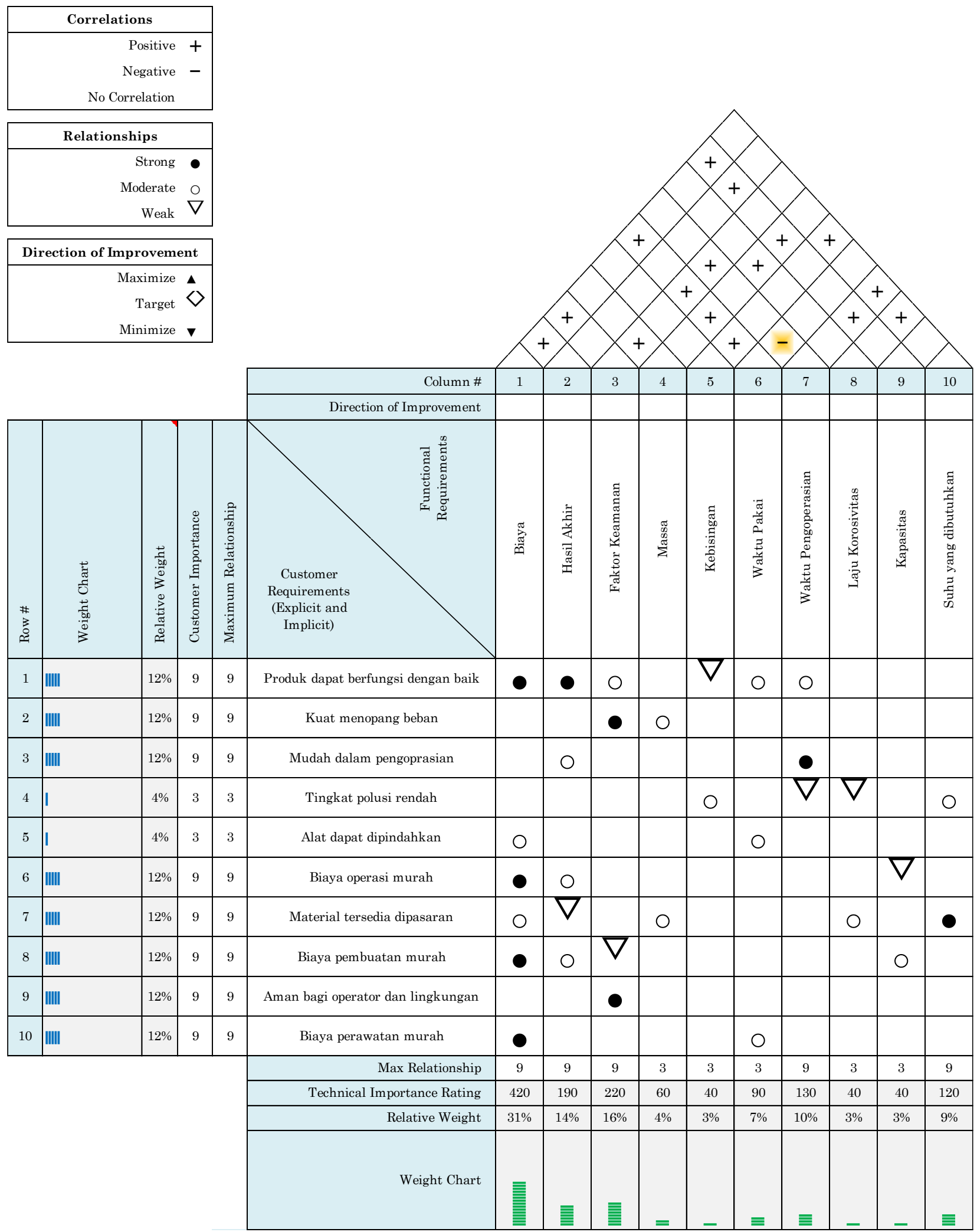

Gambar 2. House Of Quality perancangan alat pirolisis asap cair untuk pengawetan ikan bandeng

\subsection{Penentuan Varian Terbaik}

Tahap penentuan varian terbaik merupakan tahap penjabaran varian yang mungkin diaplikasikan pada alat pirolisis ini dari varian fungsi, varian bentuk, hingga varian fisik. Lalu membuat tabel agar dapat dipilih varian terbaik dengan 
mempertimbangkan keuntungan dan kerugian dari beberapa varian. Varian-varian ini diambil dari alat pirolisis yang sudah ada serta dari literatur yang sudah ada tentang perancangan alat pirolisis penghasil asap cair.

Dalam perancangan alat pirolisis, beberapa komponen memiliki varian varian yang memiliki kekurangan serta kelebihan, maka akan dijabarkan beberapa varian komponen yang digunakan serta beberapa varian terbentuk.

Tabel 3. Varian fungsi

\begin{tabular}{clcc}
\hline No. & Varian Fungsi & A & B \\
\hline 1 & Proses Pembakaran & Gas LPG & Listrik \\
2 & Proses Pendinginan & Air & Udara \\
3 & Mekanisme Pembakaran & Tertutup & Terbuka \\
4 & Arah Aliran Kondensor & Counter Flow & Parallel \\
\hline
\end{tabular}

Dari tabel 3 varian fungsi, maka didapatkan 16 varian kandidat yang dapat menjadi rancangan reaktor pirolisis asap cair untuk pengawetan ikan bandeng terpilih. Ke 16 varian tersebut adalah sebagai berikut:

Varian 1: (1A-2A-3A-4A): gas LPG - air - tertutup - counter flow; Varian 2: (1A-2A-3B-4A): gas LPG - air - terbuka counter flow; Varian 3: (1A-2B-3A-4A): gas LPG - udara - tertutup - counter flow; Varian 4: (1A-2B-3B-4A): gas LPG - udara - terbuka - counter flow; Varian 5: (1B-2A-3A-4A): listrik - air - tertutup - counter flow; Varian 6: (1B-2A-3B4A): listrik - air - terbuka - counter flow; Varian 7: (1B-2B-3A-4A): listrik - udara - tertutup - counter flow; Varian 8: (1B-2B-3B-4A): listrik - udara - terbuka - counter flow; Varian 9: (1A-2A-3A-4B): gas LPG - air - tertutup - paralel; Varian 10: (1A-2A-3B-4B): Gas LPG - air - terbuka - paralel; Varian 11: (1A-2B-3A-4B): gas LPG - udara - tertutup paralel; Varian 12: (1A-2B-3B-4B): gas LPG - udara - terbuka - paralel; Varian 13: (1B-2A-3A-4B): listrik - air tertutup - paralel; Varian 14: (1B-2A-3B-4B): listrik - air - terbuka - paralel; Varian 15: (1B-2B-3A-4B): listrik - udara - tertutup - paralel; Varian 16: (1B-2B-3B-4B): listrik - udara -terbuka - paralel.

Dari tabel pemilihan varian terbaik pada alat pirolisis di bawah (tabel 4) telah diambil beberapa keputusan utama yaitu:

1. Varian 4 yaitu Gas LPG - Udara - Terbuka - Counter Flow sesuai dengan penjelasan tabel 4 bahwa secara prinsip dapat diwujudkan tetapi keamanan dalam penggunaan alat ini perlu ditinjau kembali karena proses pembakaran suhu tinggi di tempat terbuka itu membahayakan lingkungan sekitar serta efisiensi dari penggunaan proses pendinginan oleh udara dinilai kurang efisien. Kelebihan dari varian ini adalah biaya yang dikeluarkan tidak banyak.

2. Varian 5 menggunakan listrik, sehingga membutuhkan komponen lain yang berkaitan dengan kelistrikan. Namun, kekurangan varian 5 yaitu dinilai kurang safety karena penggunaan daya listrik yang besar dan membutuhkan biaya tambahan lagi untuk komponen kelistrikannya.

Dari 2 varian di atas (varian 4 dan varian 5) telah dilakukan analisa dan pertimbangan bahwa varian terbaik yang dipilih yaitu varian 4 karena memenuhi daftar spesifikasi serta parameter yang ada sesuai dengan daftar spesifikasi pada tabel 4 . 
Tabel 4. Pemilihan varian terbaik

Pemilihan Varian Terbaik

(+) $\mathrm{Ya}$

(-) Tidak

(?) kurang informasi

(!) Tinjau kembali

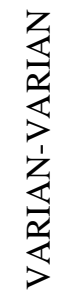

Daftar spesifikasi

Kompatible untuk fungsi keseluruhan

Memenuhi kebutuhan spesifikasi

Secara prinsip dapat diwujudkan

Safety

Lebih sederhana

Informasi memadai

\begin{tabular}{|c|c|c|c|c|c|c|c|c|}
\hline & A & B & $\mathrm{C}$ & $\mathrm{D}$ & $\mathrm{E}$ & $\mathrm{F}$ & Keterangan & \\
\hline V1 & + & + & + & + & + & + & Varian yang dipilih & + \\
\hline $\mathrm{V} 2$ & + & + & + & $!$ & + & $?$ & kurang safety & - \\
\hline V3 & - & - & + & $!$ & - & $?$ & Kurang safety dan efisiensi rendah & - \\
\hline V4 & - & - & + & $!$ & + & $?$ & Kurang safety dan efisiensi rendah & - \\
\hline V5 & + & + & + & $?$ & - & $?$ & Efisiensi rendah dan kurang safety & - \\
\hline V6 & - & + & + & - & + & + & Kurang safety & - \\
\hline V7 & - & + & + & + & - & $?$ & Efisiensi rendah & - \\
\hline V8 & $?$ & + & + & - & + & + & Kurang safety dan efisiensi rendah & - \\
\hline V9 & - & + & + & - & - & $?$ & Efisiensi rendah & - \\
\hline V10 & + & + & + & - & - & + & Kurang safety & - \\
\hline V11 & + & + & + & + & - & $?$ & Overcost dan efisiensi rendah & - \\
\hline $\mathrm{V} 12$ & + & + & + & - & + & $?$ & Efisiensi rendah & - \\
\hline V13 & + & + & + & - & - & $?$ & Kurang safety dan efisiensi rendah & - \\
\hline V14 & + & + & + & - & + & + & Kurang safety & - \\
\hline V15 & + & + & + & + & - & $?$ & Efisiensi rendah & - \\
\hline V16 & + & + & + & - & + & $?$ & Kurang safety dan efisiensi rendah & + \\
\hline
\end{tabular}

\subsection{Konsep Alat}

Pada konsep alat ini akan dijelaskan beberapa konsep yang bisa digunakan pada alat pirolisis yang dibuat. Pada penjelasan konsep alat ini akan dijelaskan pada tabel 5 dan 6.

Berdasarkan konsep-konsep yang sudah dipaparkan diatas maka dilakukan proses screening untuk memilih konsep terbaik sesuai kebutuhan dari user serta beberapa pertimbangan untuk manufaktur alat. Penentuan pemilihan varian terbaik pada pembahasan sebelumnya tentang varian fungsi untuk proses pembakaran, proses pendinginan, mekanisme pembakaran dan arah aliran kondensor telah ditetapkan sesuai dengan kebutuhan dari user serta beberapa pertimbangan 
Dhimas Satria dkk /Jurnal Rekayasa Mesin

p-ISSN: 1411-6863, e-ISSN: 2540-7678

Vol.16, No.2, Agustus 2021, hal. 189-199

manufaktur alat. Adapun keseluruhan pemilihan konsep terbaik dan penentuan varian terbaik yang dapat dikembangkan yatu:

1. Proses pembakaran : mengunakan gas LPG

2. Proses pendinginan : menggunakan air

3. Mekanisme pembakaran : tertutup (menggunakan drum)

4. Arah aliran kondensor : counter flow (berlawanan arah)

5. Konsep bentuk alat : silinder

Tabel 5. Konsep bentuk alat pirolisis asap cair untuk pengawetan ikan bandeng

\begin{tabular}{|c|c|c|c|}
\hline $\begin{array}{l}\text { Konsep } \\
\text { Bentuk }\end{array}$ & Gambar & Keterangan & Penjelasan \\
\hline Balok & & $\begin{array}{l}\text { Cost tinggi, } \\
\text { efisiensi } \\
\text { rendah. }\end{array}$ & $\begin{array}{l}\text { Proses pada bentuk ini adalah bahan baku dimasukan pada } \\
\text { reaktor dengan membuka tempat masukan bahan baku setiap } \\
\text { memulai begitupun setelah selesai penggunaan. }\end{array}$ \\
\hline Silinder & & $\begin{array}{l}\text { Sesuai dengan } \\
\text { kebutuhan. }\end{array}$ & $\begin{array}{l}\text { Proses pada bentuk ini adalah bahan baku dimasukan lewat } \\
\text { bagian atas reaktor setelah baut-baut yang terdapat pada alat } \\
\text { dikendurkan, begitupun setelah penggunaan untuk membuang } \\
\text { sisa bahan baku pembakaran. }\end{array}$ \\
\hline
\end{tabular}

Tabel 6. Konsep pembakaran alat pirolisis asap cair untuk pengawetan ikan bandeng

Gambar

Konsep Pembakaran

Keterangan

Utuh Potongan

Terbuka
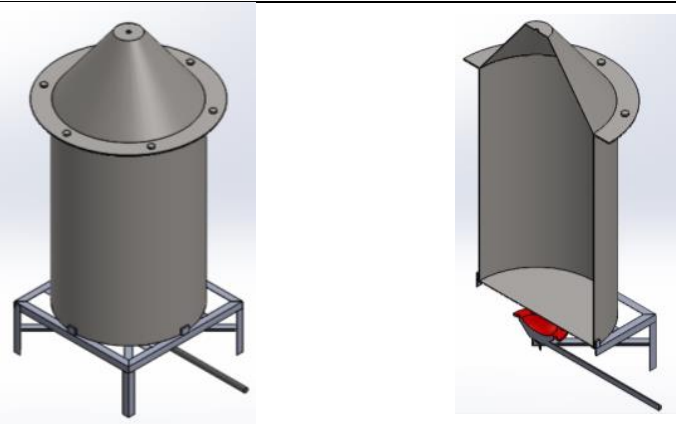

Efisiensi rendah, kurang safety. 
Dhimas Satria dkk /Jurnal Rekayasa Mesin

p-ISSN: 1411-6863, e-ISSN: 2540-7678

Vol.16, No.2, Agustus 2021, hal. 189-199

\begin{tabular}{ccc}
\hline \multirow{2}{*}{ Konsep Pembakaran } & \multicolumn{3}{c}{ Gambar } \\
\cline { 2 - 4 } Tertutup & Utuh & Seterangan \\
\hline
\end{tabular}

\section{Kesimpulan}

Konsep desain alat pirolisis asap cair untuk pengawetan ikan bandeng terbaik yaitu Varian 4 yaitu gas LPG - udara terbuka - counter flow. Adapun keseluruhan pemilihan konsep desain terbaik yaitu: proses pembakaran mengunakan gas LPG, proses pendinginan menggunakan air, mekanisme pembakaran adalah tertutup (menggunakan drum), arah aliran kondensor adalah counter flow (berlawanan arah), dan konsep bentuk alat adalah silinder.

\section{Daftar Pustaka}

[1] L. Sahubawa and Ustadi, Teknologi Pengawetan dan Pengolahan Hasil Perikanan. Gama Press, 2014.

[2] S. Soldera, N. Sebastianutto, and R. Bortolomeazzi, "Composition of Phenolic Compounds and Antioxidant Activity of Commercial Aqueos Smoke Flavorings," J Agric Food Chem, vol. 56, pp. 2727-2734, 2008.

[3] M. Wijaya, E. Noor, T. Irawadi, and G. Pari, "Karakterisasi komponen kimia asap cair dan pemanfaatannya sebagai biopestisida," Bionature, vol. 9, pp. 34-40, 2008.

[4] F. Fatimah and S. Gugule, "Penurunan Benzo[A]Pirena Asap Cair Hasil Pembakaran," Chem.Prog, vol. 2, no. 1, 2009.

[5] Y. Prihandana and H. Roy, Energi Hijau. Jakarta: Penebar Swadaya, 2007.

[6] S. Husseinsyah and M. Mosthapa, "The Effect of Filter Content on Properties of Coconut Shell Filled polyester Composites," Malaysian Polym. J., vol. 6, no. 1, pp. 87-97, 2011.

[7] J. . Girrard, Technology of Meat and Meat Products. New York: Ellis Horwood, 1992.

[8] P. Darmadji, "Produksi Asap Rempah dari Limbah Padat dengan Cara Pirolisis," Majalah Ilmu dan Teknologi Pertanian, Yogyakarta, 1996.

[9] E. Prasetyo, "Pengawetan Ikan Bandeng Segar Menggunakan Ekstrak Teh Hijau," 2011. http://rabbitsaga.com/668/pengawetan-ikan-bandeng-segar-menggunakan-ekstrak-teh-hijau.html (accessed Mar. 07, 2021).

[10] K. B. Reta, "Pembuatan Asap Cair Dari Tempurung Kelapa,Tongkol Jagung, Dan Bambu Menggunakan Proses Slow Pyrolysis," Universitas Tribhuwana Tunggadewi Malang, 2013.

[11] E. P. Mentari, "Pembuatan Dan Pengujian Asap Cair Dari Tempurung Kelapa Dan Tongkol Jagung Sebagai Bahan Pengawet Ikan,” Universitas Makassar, 2017.

[12] S. Syafri and S. A. Novita, "Rancang Bangun dan Uji Kinerja Alat Pembuat Asap Cair," J. Teknol. Pertan. Andalas, vol. 17, no. 1, 2013. 
Dhimas Satria dkk /Jurnal Rekayasa Mesin

p-ISSN: 1411-6863, e-ISSN: 2540-7678

Vol.16, No.2, Agustus 2021, hal. 189-199

[13] G. Pahl and W. Beitz, Engineering Design: A Systematic Approach, Second Edi. London: Springer-Verlag, 1996.

[14] D. Satria, R. Lusiani, I. Rosyadi, E. Listijorini, A. Aswata, and Y. Hermawan, "Analisa Performa Mesin Stirling Tipe Alpha Inovasi Desain Sudut Fasa 180 derajat,” J. Rekayasa Mesin, vol. 15, no. 1, pp. 33-41, 2020, doi: http://dx.doi.org/10.32497/jrm.v15i1.1839.

[15] D. Satria, E. Listijorini, and M. N. Nurghodan, "Perancangan Sistem Kendali Suhu Pada Mesin Pengering Hybrid Menggunakan Metode Fuzzy Logic,” J. Ilm. Rekayasa Pertan. dan Biosist., vol. 3, no. 2, pp. 179-185, 2015, [Online]. Available: http://jrpb.unram.ac.id/index.php/jrpb/article/view/32/23.

[16] L. Cohen, Quality Function Deployment: How to Make Qfd Work for You, 1st editio. Prentice Hall, 1995.

[17] D. Satria, S. Susilo, R. Lusiani, and Y. Hermawan, "Design of alpha type stirling machine biomass-based innovation design with the capacity of 100 watt Design of alpha type stirling machine biomass-based innovation design with the capacity of 100 watt," 2019, doi: 10.1088/1757-899X/673/1/012124.

[18] D. Satria et al., "Pengaruh Waktu Tahan Proses Pack Carburizing Baja AISI 3115 dengan Menggunakan Calcium Carbonat dan Batubara Sub Bituminous dan Mendapatkan Perlakuan Panas Quenching Media Pendingin Air,” Rotasi, vol. 21, no. 2, p. 88, 2019, doi: 10.14710/rotasi.21.2.88-95. 